\title{
SIGNIFICANCE OF TOURISM AND LOCAL COMMUNITIES
}

\author{
A study of the shift in valuation criteria of Japanese protected townscapes \\ 観光と町の共同体 \\ 日本における町並み保存に対して評価基準の変化 \\ Jon ALVAREZ* \\ アルバレス ジョン
}

\begin{abstract}
The main goal of this paper is to explain, on the one hand, how protected townscape designations evolved due to new theoretical lines and new policies, while on the other hand, explaining how this evolution allowed some townscapes to enter the denken chiku designation, while it would have been unlikely for them to have entered that same designation back in 1975. The main hypothesis is that the shift has driven the denken chiku designation system from tourism and economic development viewpoint to a local, community based model, in which tourism is not seen as the goal itself but, at the most, as a booster for local life. For this purpose, a comprehensive documentation and on-site research has been conducted. Starting from laws related to cultural protection and economic growth, every townscape designated denken chiku has been analyzed in terms of location, townscape typology, designation year, urban or rural nature and accessibility to traffic infrastructures developed over the last 40 years.
\end{abstract}

Keywords: Important Groups of Traditional Buildings, valuation criteria, tourism, development, infrastructure 重要伝統的建造物群, 評価基準, 観光, 成長, 交通機関

\section{Introduction}

When in 1975, the Cultural Properties Protection Law bunkazai hogohō was modified, the protection of Important Groups of Traditional Buildings (jūyō dentōteki kenzōbutsugun, from now on denken chiku) was introduced. The following year, the first seven denken chiku were designated by the Agency of Cultural Affairs (ACA). The starting dates of Japanese townscape conservation are quite similar to those of European countries. Notwithstanding, the origin of Japanese townscape conservation is unique when compared to western countries.

In Europe, despite efforts by some professionals like Giovannoni, to recognise the inherent value of the built environment, that is, towns and minor architecture as a whole (Carbonara, 1997; Giovannoni, 1998), the post-war emergency state caused warring countries to give preference to the recovery of singular monuments and their locations. In the 1960s, the Venice Charter (ICOMOS, Venice Charter, 1964, Art 6) reintroduced the concept of the built environment, for singular monuments. Thus, the urban fabric was considered valuable provided that it was related to monuments, but it was not valued as a whole, like it had been in the initial definition by Giovannoni.

By contrast, Japanese initiatives came from two research lines and two law corpora, both developed mainly in the 1950s: the protection of landscape and the protection of traditional minka hous- es. In Japan, the term kenzōbutsugun (groups of traditional built structures) is used instead of 'environment', (the spatial frame surrounding monuments). Minka or machiya housing groups were valuable in themselves, regardless of whether any monument in particular existed within the group. However, many traditional building groups were disappearing, because the tendency toward scrap-and-build, which was made possible due to the strong landowner rights (Yamasaki, 2005), arising out of the 1960s. Avoiding scrap-and-build activity would become the initial goal of townscape preservation. Later, new goals would rise, such as giving some development opportunities to declining townscapes, or using townscapes as tourist assets.

Over the past 40 years, the development of designation for new denken chiku have evolved due to the redefinition of the goals of townscape protection. This article aims to explain this redefinition process by looking at the evolution of denken chiku nominations. Consequently, this research process includes an examination of the earlier documentary evidence (laws, publications by authorities), a detailed documentary study (surveys and ordinances by municipalities) and an in-place survey in the denken chiku. For the purpose of studying the valuation of denken chiku as tourist assets, the research process focuses on accessibility to tourists: consultation of the 'Chiriin chizu' map database (https://maps.gsi.go.jp) and visits to denken chiku by means of public transportation. Accessibility

* Ph. D. student, Dept. of Architecture, Grad. Sch. of Creative Science and Engineering, Waseda University

早稲田大学創造理工研究科建築学専攻建築史研究室 博士後期課程 
information and pamphlets by tourism offices of each denken chiku have been used to complete the analysis.

\section{The temporal evolution of the denken chiku system}

In this section, the evolution of the denken chiku system is described through four factors related to the valuation of the townscapes: publications and activities by local and national authorities, legislation, scholarly activity and support by local communities. In all their publications, the ACA classifies townscapes into eight categories, in order to determine the value of each desig-

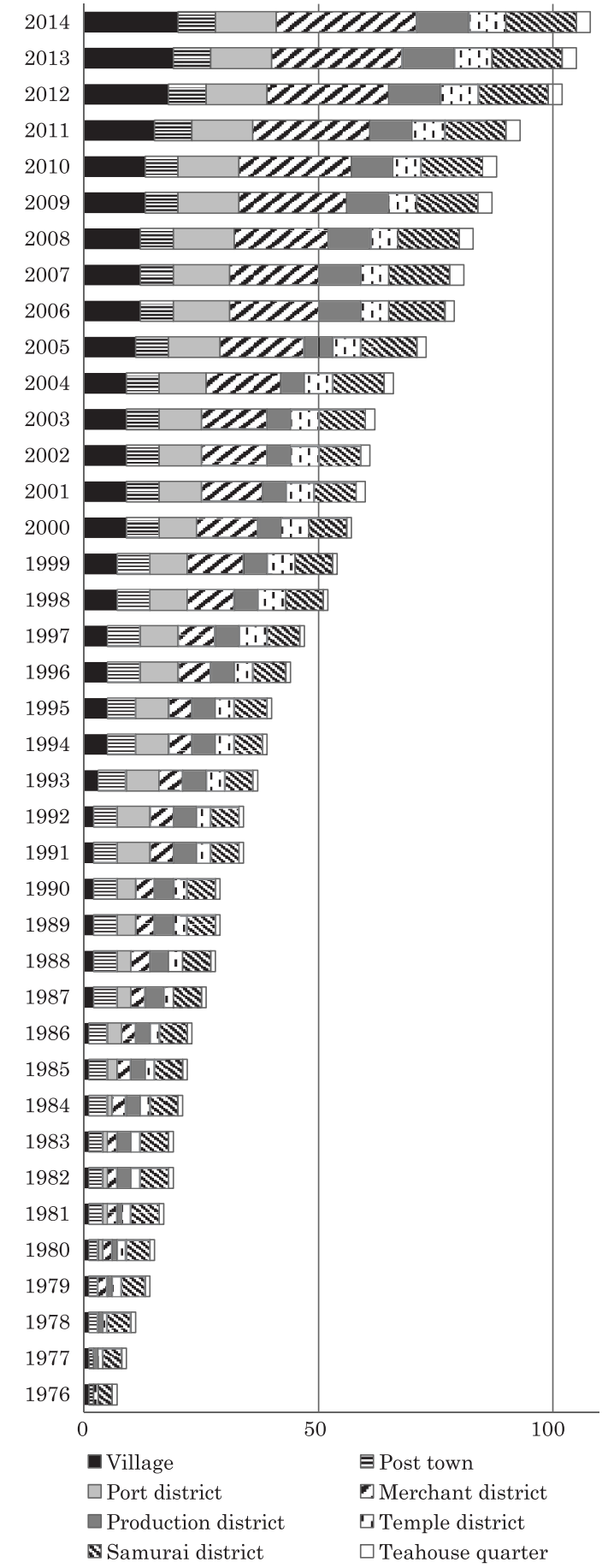

Fig.1 evolution of number of denken chiku nated townscape and to make it public. These categories are: village, post town, port district, merchant district, district related to an industrial activity, temple and shrine district, castle and samurai district, and tea house and amusement quarter. But in the last 50 years, the growth in the number of districts within each typology has not been uniform (fig.1). Firstly, the overall rate of growth has increased significantly over the last 25 years. Secondly, the typologies that grew rapidly at first are not the same as the typologies that are currently growing. To discover the causes of these temporal changes, a temporal analysis of different laws and events has been performed, taking into consideration the events and laws from both before and after the 1975 revision of the Law of Cultural Properties (fig.2). Four stages can be distinguished as described below.

\subsection{Stage 0,1960-1975. Before denken chiku system}

Prior to the 1975 law, the basis for law was a combination of landscape protection and scholarly interest towards minka houses. Kyoto started efforts to institute townscape preservation: Kyoto landscape protection ordinances (1930) established protection for the surrounding mountain areas, but also for the old Heiankyō capital urban grid area (Nitschke, 1998). This area suffered modifications for evacuation purposes in World War II, and for 'motorization' after the war (Nishiyama, 1990). Even the new high speed train was supposed to run across the very centre of the city. Events such as these worried the citizens, thus resulting in the first citizen association for landscape protection. The government also published the Law for the Protection of Ancient Capital Cities in 1966. This law included eight ancient cities and their landscapes.

At the same time, the traditional rural houses (minka) and urban houses (machiya) started to be acknowledged as objects to protect. Before that, Japan was no different from other countries. The preservation policies started with ancient temples and singular buildings. It does not necessarily mean that there was no academic interest in popular houses in early times, but they were not preserved as valuable. Most of the minka that were studied were still in their original locations, but they were left as they were, rather than purposely kept (Nakatani et al., 2013). The shift started after the 1950 law was published. The four categories of criteria set out for the building designation included 'buildings with outstanding design', 'buildings with outstanding technique', 'buildings with historical value' and 'buildings typical for a region or period' (Japan Government, 1950). While the former three categories were meant for religious and public buildings from the past, the latter introduced the 'typical' attribute, also applicable to houses. And while protected religious buildings constituted the vast majority (Henrichsen, 1998), scholarly interest in traditional minka houses grew. Between 1962 and 1965, the Commission for Cultural Properties (now merged into the Agency for Cultural Affairs) surveyed and designated as cultural properties 250 houses throughout Japan. 
In an effort to protect these kind of houses from disappearing, several buildings were moved into traditional architecture museums, called minkaen. The first open air museum was opened in Hida-Takayama in 1959. Other museums were opened some time later to protect houses of specific typologies or environments, such as Meijimura (Inuyama), or Edomura (Kanazawa). Some others like Bōsō no Mura (Chiba) would describe the typical traditional environment of their region. In other words, the 'typical' attribute from the 1950 law derived into a creation of typologies, and as a result, typological environment reproductions were created.

\begin{tabular}{|c|c|c|c|c|}
\hline Year & Laws & Events & Publications & \\
\hline-1959 & 1950: Law of Cultural Properties & $\begin{array}{l}\text { 1949: Fire at Horyuji temple } \\
\text { 1959: First open air museum in Hida }\end{array}$ & & \multirow[b]{3}{*}{ 孚 } \\
\hline $\begin{array}{c}1960^{-} \\
1964\end{array}$ & $\begin{array}{l}\text { 1961: Plan for Doubling National Income } \\
\text { 1962: 1st Comprehensive National Develop- } \\
\text { ment Plan } \\
\text { Malraux Law in France: First law for town- } \\
\text { scape protection ever. }\end{array}$ & $\begin{array}{l}\text { 1960: Project for a New Tokyo inside the Bay } \\
\text { 1961: AIJ establishes the Subcommittee for } \\
\text { research on historic buildings } \\
\text { 1963: Kamakura Landscape Preservation } \\
\text { Society buys } 1.5 \text { Ha of land around Tsurugaoka } \\
\text { Shrine. } \\
\text { 1964: Tokyo Olympic Games. Tōkaidō Shinkan- } \\
\text { sen. Protest against Kyoto Tower. }\end{array}$ & $\begin{array}{l}\text { 1962-65: Survey by the Commission for } \\
\text { Cultural Properties: } 250 \text { houses desig- } \\
\text { nated as National Cultural Properties } \\
\text { 1964: Venice Charter }\end{array}$ & \\
\hline $\begin{array}{c}1965^{-} \\
1969\end{array}$ & $\begin{array}{l}\text { 1966: Law for Conservation of Ancient Capital } \\
\text { Cities (Kyoto, Nara, Kamakura) } \\
\text { 1968: Law of Urban Planning. First protection } \\
\text { ordinances: Kurashiki, Kanazawa. } \\
\text { 1969: 2nd Comprehensive National Develop- } \\
\text { ment Plan }\end{array}$ & $\begin{array}{l}\text { 1965: Meijimura Open Air Museum } \\
\text { 1966: Takayama Sannocho Association is } \\
\text { founded as the first for townscape protection } \\
\text { 1967: Edomura Open Air Museum } \\
\text { 1968: Creation of the ACA. Creation of the } \\
\text { Association of Friends of Tsumago }\end{array}$ & 1968: TANGE, K. 'Nihon no toshi kūkan' & \\
\hline $\begin{array}{l}1975^{-} \\
1979\end{array}$ & $\begin{array}{l}\text { 1975: Revision of Law of Cultural Properties } \\
\text { 1977: 3rd Comprehensive National Develop- } \\
\text { ment Plan. Oriented towards balance between } \\
\text { regions }\end{array}$ & $\begin{array}{l}\text { 1975: International Year of Cultural Heritage. } \\
\text { 1976: First } 7 \text { denken are designated. } \\
\text { 1979: Municipalities found the Association for } \\
\text { the Protection of Denken Chiku. }\end{array}$ & $\begin{array}{l}\text { 1975: Amsterdam Charter } \\
\text { 1979: Publication of a survey in } \\
\text { Sanneizaka. The strategy preserves } \\
\text { building uses. }\end{array}$ & \multirow[b]{2}{*}{ 窎 } \\
\hline $\begin{array}{c}1980^{-} \\
1984\end{array}$ & $\begin{array}{l}\text { 1980: Asuka Law. First law in protecting a } \\
\text { town and its landscape. } \\
\text { 1982-87: Nakasone government deregulations. } \\
\text { 1983: Ministry of Construction establishes a } \\
\text { Model Program for Townscape Development, } \\
\text { not restricted to historic towns. }\end{array}$ & & $\begin{array}{l}\text { 1982: Association for Townscape Pres- } \\
\text { ervation publishes 1st issue of their } \\
\text { bulletin. }\end{array}$ & \\
\hline $\begin{array}{c}1990^{-} \\
1994\end{array}$ & $\begin{array}{l}\text { 1990: Ministry of Construction changes its } \\
\text { program name to Model Urban Planning for } \\
\text { Attractive and Green Townscapes } \\
\text { 1992: Ministry of Land introduces a less } \\
\text { restrictive program, called Program for the } \\
\text { Improvement of Townscape Environment. It } \\
\text { includes the implementation of community } \\
\text { centres and public services. }\end{array}$ & $\begin{array}{l}\text { 1991: End of bubble economy. } \\
\text { 1994: Nara World Heritage Convention. Publi- } \\
\text { cation of the Nara Document. }\end{array}$ & $\begin{array}{l}\text { 1990: NISHIYAMA, U: 'Rekishite- } \\
\text { ki keikan to machizukuri'. Critic to } \\
\text { Nakasone's 4th Development Plan. The } \\
\text { author states that the violent increase } \\
\text { of land price is a cause for the intensive } \\
\text { land use and environment destruction. } \\
\text { 1994: LARSEN, K.E 'Architectural } \\
\text { Preservation in Japan'. }\end{array}$ & \\
\hline $\begin{array}{l}1995^{-} \\
1999\end{array}$ & $\begin{array}{l}\text { 1996: Amendment of Law of Cultural Proper- } \\
\text { ties. In order to stop the loss of buildings by } \\
\text { deregulations, a new system of registration is } \\
\text { established. The new registered building cate- } \\
\text { gory is less restrictive than the designation as } \\
\text { National Cultural Property. }\end{array}$ & $\begin{array}{l}\text { 1995: Gasshozukuri villages as UNESCO } \\
\text { World Heritage. }\end{array}$ & $\begin{array}{l}\text { 1997: ENDERS, S, GUTSCHOW, N. } \\
\text { 'Hozon'. Cases of tourism negative } \\
\text { impact (Sanneizaka) and cases of local } \\
\text { people participation (Imaicho) are } \\
\text { explained. } \\
\text { HOHN, Uta 'Townscape Preservation in } \\
\text { Japanese Urban Planning' }\end{array}$ & 臰 \\
\hline \multirow[t]{2}{*}{$\begin{array}{l}2000^{-} \\
2004\end{array}$} & 2001: First revision of Law of Urban Planning & & $\begin{array}{l}\text { 2003: ACA. 'Nōrinsui sangyō ni kansuru } \\
\text { bunkateki keikan no hogo ni kansuru } \\
\text { chōsa kenkyū' }\end{array}$ & \\
\hline & 2004: Law of Landscape. & & & \multirow{3}{*}{ 孚 } \\
\hline $\begin{array}{c}2005^{-} \\
2009\end{array}$ & $\begin{array}{l}\text { 2006: Second revision of the Law of Urban } \\
\text { Planning, oriented to 'machizukuri' } \\
\text { 2007: Law of Historical Machizukuri }\end{array}$ & $\begin{array}{l}\text { 2007: Iwami Ginzan area as UNESCO World } \\
\text { Heritage. }\end{array}$ & & \\
\hline $\begin{array}{l}2010^{-} \\
2015\end{array}$ & & & $\begin{array}{l}\text { 2015: ACA. 'Rekishi wo ikashita } \\
\text { machizukuri' }\end{array}$ & \\
\hline
\end{tabular}

Fig. 2 chronology of laws and events related to townscape nationwide in Japan 
The final part of this stage came after local communities formed to protect their buildings in their original sites. The Ancient Capital law protected only the landscape in the ancient capital cities, but the citizens of smaller towns had the same worries. This, along with the growing appreciation of traditional houses, led to the creation of local associations for townscape protection. The first association was founded in Takayama in 1966; seven years after Hida museum had opened and several old houses from Takayama had been moved there. In the meantime, the 1968 Law for Urban Planning enabled municipalities to determine planning areas with specific ordinances. Some municipalities published the first townscape preservation ordinances in the same year (fig.2). These ordinances were established with the support ofthe citizen association and the establishment of local ordinances. Later, the Agency of Cultural Affairs started surveys to include those towns in the protected list as a new category. When in 1975, an amendment to the law included the denken chiku, some protected towns moved to the new system ruled by the Agency of Cultural Affairs, while others stayed with their local ordinance under the Law for Urban Planning.

\subsection{Stage 1, 1975-1990: urban locations, archetypical towns.}

The 15 years following the 1975 legal amendment were characterized by a large number of surveys of townscapes, although few denken chiku were nominated. In 1976, seven districts which had their own ordinances were included into the denken chiku category, although few others were included after that. Most of the townscapes in urban locations were included during this period: until 1990, Kyoto hosted four of the 29 denken chiku. This is often described as a reaction caused by the deregulation policies of Prime Minister Nakasone (Nishiyama, 1990; Hohn, 1997): rising in land prices, especially in urban areas, caused the scrap of several old houses. Instead, the idea of the modernisation of cities led to the introduction of modern skyscrapers as new symbols and monuments (Nishiyama, 1990).

From a theoretical perspective, the above-mentioned concepts of landscape and housing typology were present in several surveys, both in urban locations, like Sanneizaka district in Kyoto (Fig.5 district number.4), or rural districts like Yōkaichi in Ehime (Fig.5 number 18), or Fukiya in Okayama (Fig.5 number 8)(Hohn, 1998; Suzuki et al., 1980; Nariwa Town, 1977). In the case of Fukiya, even the minka research was not exhaustive: just some example houses from the three house types defined in the survey report.

Regarding townscape types, those growing the fastest were the post towns, samurai or castle towns, and at a smaller range, productive districts and merchant districts. In most of surveys, districts were named after one of the eight types defined by the ACA: Tsumago (Fig.5, number 2) is clearly defined as a post town; likewise, Kakunodate (Fig.5, number 1) is defined as a samurai town; Fukiya as a production town, and so on. Very few are described as an individual result of mixing several typologies, like
Yōkaichi (Uchiko Town, 1983). Instead, the main trend when it comes to preservation involving a typology and a period in which each district was built, and bringing all traditional buildings back to that defined period, like in Tsumago (Hohn, 1998). Preservation works focused on the external shape of the town and houses, often changing the use of the interiors of the houses. In Tsumago, house typology was transformed from old post to new shop-dwelling use: the dwelling was moved entirely to the second floor, thus being the ground floor empty after shop closing time (Ueno, 2011). The shape was preserved, but the social use of the space was severely altered. Furthermore, the treatment of the external aspect was broadly based on defined typologies rather than historical evidence. In Narai (Fig. 5, number 11), external preservation was not associated with what historical Narai used to look like, but to the public perception of what Narai traditionally looked like (Ōshima, 2004). Likewise, surveys and policies in and around Yōkaichi, located in Uchiko town (Ehime), depict the concept of Uchikorashisa (lit. look like Uchiko) as a value worthy of preservation, not just regarding traditional buildings (Uchiko Town, 1983,1987).

\subsection{Stage 2, 1990-2004: rural sites after the bubble burst.}

In 1990, the Japanese economic bubble of the 1980s had burst. Townscape protection suffered both positive and negative effects as a result of that burst. On the negative side, tourism decreased. On the positive side, speculation on old towns also decreased. The government increased the budget for denken chiku to avoid the negative effects (ACA, 2015). The number of structures declared denken chiku increased remarkably after 1990.

Scholarly activity also grew over the course of the 1990s. Several scholars, both Japanese and foreign, carried out their own surveys. In fact, the most complete reference books about preservation in Japan were written in the 1990s (Fig.2). During this period, denken chiku, not specific to urban settlements, increased: merchant towns attached to historic routes, as well as port towns, were the main typologies at this stage. Many of the denken chiku from stage 2 were surveyed before 1990, but their nomination took longer, sometimes over a decade (Kobayashi \& Kawakami, 2003).

In the Japanese scholarly activity, the term machizukuri (lit. 'town making') was spread. Local communities grew in Japan to build self-organized town preservation committees, against deregulations and the polarization of economic activities of the $1980 \mathrm{~s}$ into big cities. Machizukuri appeared as a synonym for town preservation which was driven by the local community and their sustainable life. Starting from Kawagoe (Fig.6 number 54) in 1988, specific ordinances for machizukuri were published in several municipalities. Given that the community was the centre of any 'machizukuri' policy, several studies regarding communities in denken chiku were added to surveys. Fukiya had lost $30 \%$ of its population and $75 \%$ of its worforce since 1955 , according to a survey conducted in 1991 (Nariwa town, 1991). In a latter report 
(Takahashi city, 2013), the 'U-turn' phenomenon was seen as an issue to deal with: the 'U-turn' describes the return of the workers migrated to big cities once they have retired from active work. In Yame Fukushima (Fig.6, number 61), they aimed to attract young people from outside so that young people could open new businesses in the district.

Another element introduced in surveys during this period is the study of street façades and the characterisation of each quarter inside a district. According to surveys, these street and quarter studies were intended to solve two issues that were detected in protection during the 1980s: (a) previous surveys had considered each building independently, which made very difficult to introduce new structures into the district in a harmonious way; and (b) environmental elements, like roads, walls and urbanisation, had been omitted from previous surveys, thus causing difficulties when dealing with common services like electric lines or fire prevention equipment. The inside of buildings would also have to be more thoroughly studied: buildings not belonging to a certain typology would also be included in surveys. In some cases, like Kurayoshi (Fig.6, number 51), every intervention on a building was conducted along with a historical study of the building, which was included in the documentation of the intervention.

\subsection{Stage 3, 2004-2014: village, landscape, community}

In 2003, the Japanese government ruled by Junichirō Koizumi published Fundamental Policy Principles to Make a Beautiful Country - Utsukushii kunizukuri seisaku taikō. It was the greatest public acknowledgement of town and landscape as spatial structures, and it was intended to resolve all the disturbances that economic development introduced into the urban space (e.g. electric lines, high rise blocks, decrease of green spaces). In 2004, a specific law, the Landscape Law keikanhō was published. Also in 2004, the Cultural Properties Protection Law was modified in order to include cultural landscapes as a category. The surveys on denken chiku became more detailed: landscape and streetscape elements, such as terrace walls, waterways or signs were included. In Kyoto prefecture, Ine district (Fig.7, number 69) included the bay area in which the village is located, given that boat traffic is part of Ine community, even if it is not a street space itself (Ine town, 2005). The number of denken chiku increased further, but the village type denken chiku had the biggest increase. In rural areas, empowered communities founded NPO, associations and trusts, which helped village districts become denken chiku.

\section{The location of denken chiku: the social and economic shift.}

In this section, the evolution of the social and economic aspects of denken chiku designations are described. Both economic development and tourism have common needs: accessibility to infrastructure. Japan's uniqueness when compared to western countries is that the movement factor is included in all community spaces: in- stead of static squares or greens, they build their relation space along economic trading routes (Kōjiro et al., 1975). Japanese relate to each other while moving. By the time denken chiku system was implemented, the potential for tourism and regional transformation was higher for railway than for any other means of transportation, due to factors explained below:

1) Temporal factors: roads and expressways had a smaller impact on Japan territorial transformation, because the railway was given priority from the late 19th century to the 1970s (MLIT, 2015). The construction of the railways and development of express lines have mainly been before denken chiku designations, while car expressways and public bus transportation came later. This is true even for some recent denken chiku, like Obamanishigumi (Fig. 7, number 83), nominated before the new expressway from Osaka was built.

2) Covered territory factors: in the $1960 \mathrm{~s}$, a few kilometres of the first two expressways (Meishin and Tōmei) were built, thus the coverage by expressways was far from having real potential. Also, the type of covered territory was different: before 1990, the railway network had been built along the old Edo and Meiji period routes, connecting regions and towns in a similar way as those routes. By contrast, the new expressways ran along the older, Heian period routes, thus connecting important urban areas while neglecting some rural regions like San-In, Shikoku or eastern Kyushu (Takebe, 1985). As for public transportation, the first long-distance bus service (Tokyo-Osaka) would be opened in 1968, 4 years later than the Tokyo-Osaka shinkansen line and 5 years before Tōmei expressway was finished. In the 1990s, long distance bus networks

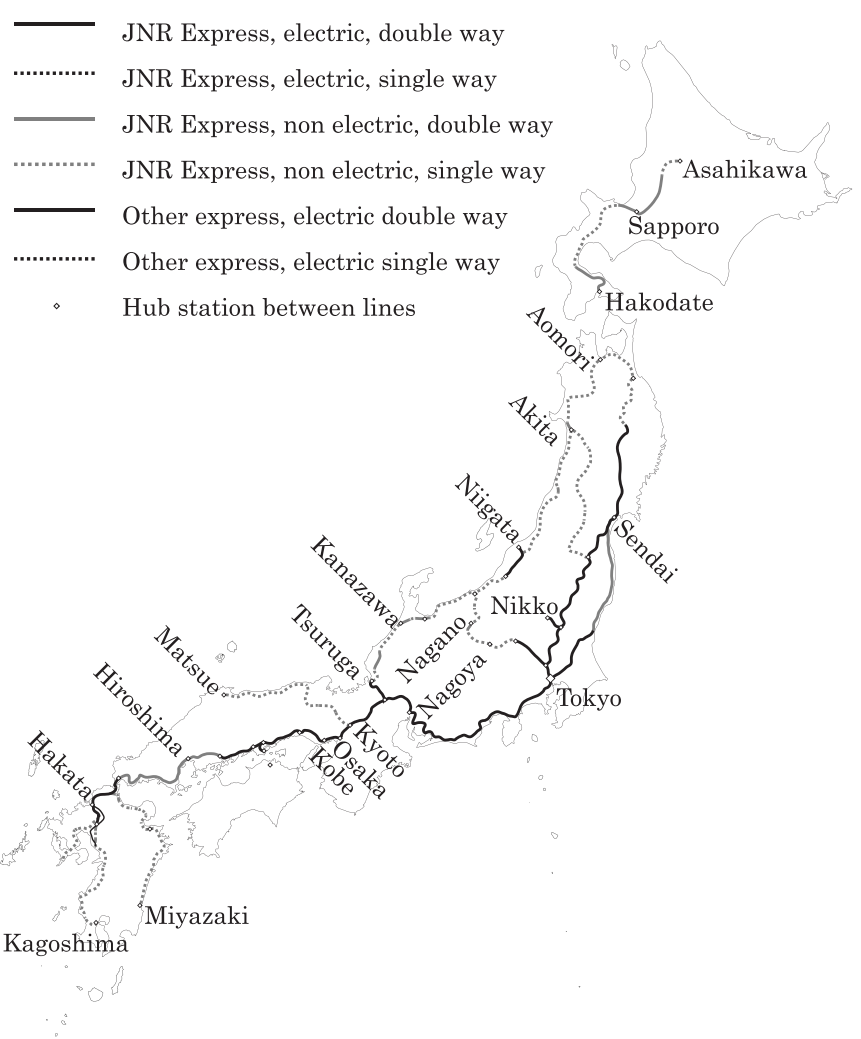

Fig.3 Map of Japanese express trains in 1961 


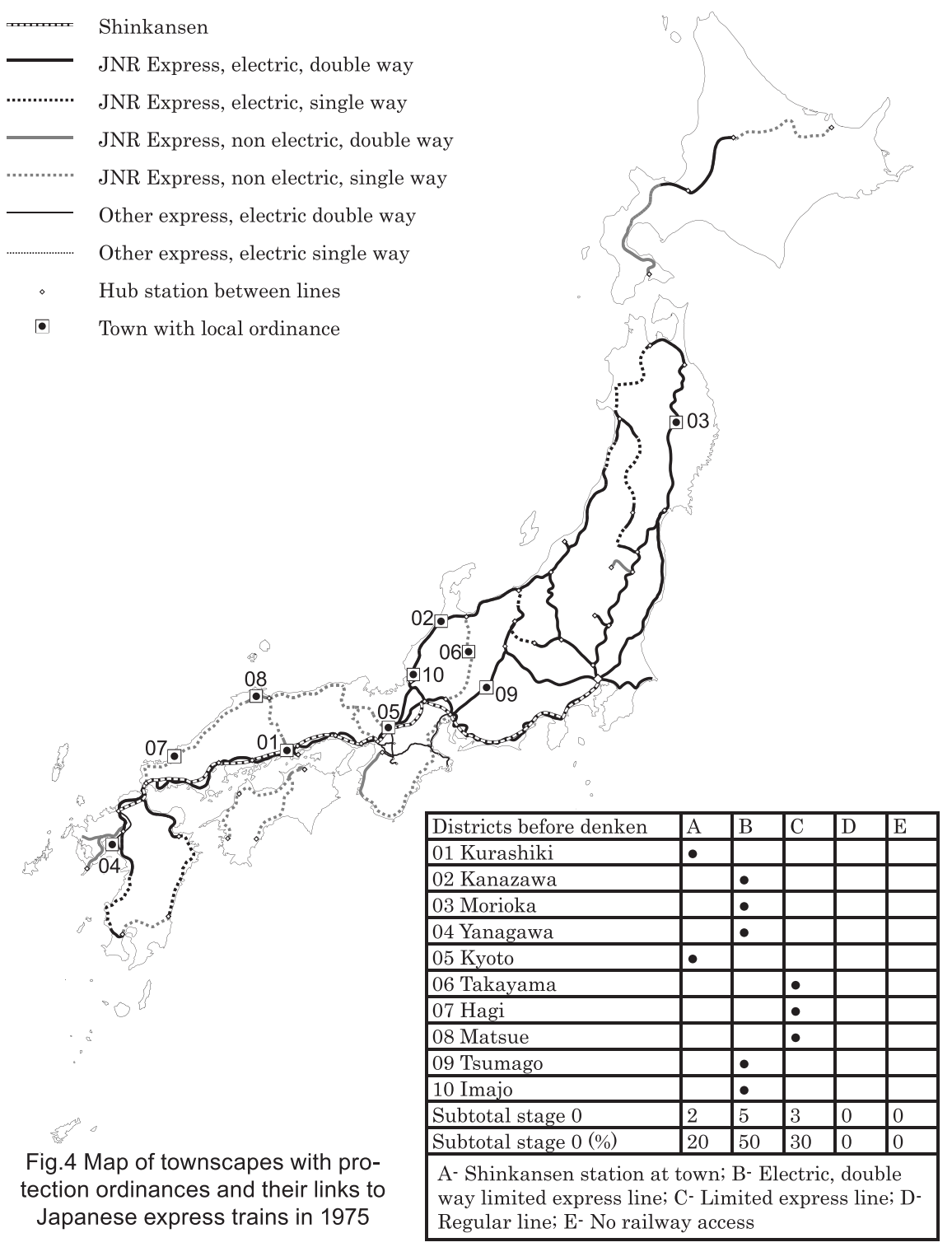

Tange's for the development of Tokyo Bay were the image of a desired new urban culture. Cities were rapidly urbanized, while more population became increasingly concentrated. Thus, a shift in the infrastructure network was projected: from a local network to a city-to-city network. This network was not just for domestic users, Japan was also being developed for tourist activity ahead of the 1964 Olympic Games, thus an express train network was developed connecting Tokyo and all major cities (Fig.3). The express network would be progressively electrified, while many local railways were still incomplete. In addition, the Tōkaidō Shinkansen was open in 1964, and limited express trains would connect Tokyo with an increasing number of urban areas and tourist assets: Nikko had their own Limited Express services from Ueno station (Fig.3), and Aizuwakamatsu would have its own line later in that decade.

The new modernity also needed urban symbols: Kyoto Tower was projected on the site of the old Japan Post headquarters. Being much higher than the local townscape, it caused one of the first popular reactions (keikan ronsō, lit. landscape disputes) against the new urban culture. As a part of that new urban culture, scrap and build activity was a risk for townscapes, especially in the most

were developed, but the biggest companies were subsidiaries of the existing railway companies, and most of services were night buses, connecting only big cities while rural areas had little service (Han, 1995). At the same period, railways were having good figures in terms of passengers and benefits, not counting local lines and third sector lines in remote rural areas (Kawashima, 1998).

3) Urban and regional transformation factors: after the Meiji period, road and fluvial transportation shifted to railway, thus altering the way Japanese used space and, in the long run, the way Japanese built relations. This is especially true in big cities like Tokyo (Jinnai, 1995), but also rural areas experienced a big change when the railway replaced the use of boats (Nishiyama, 1990).

Considering these factors, this paper focuses on the accessibility to railway infrastructure as a booster for development and tourism.

3.1. Stage 0: cities to protect their heritage, and villages to use infrastructures as an entrance for tourist activities.

Prior to the 1975 legal amendment, Japanese politicians encouraged new projects which represented the new Japan; projects like developed areas: Tokyo-Hakata axis, which also served as home to most of the new transportation infrastructures (Fig.3, Fig.4).

As opposed to urban areas, rural areas were declining, both in population and in economic activity. Most of them stayed away from the new infrastructure networks at first. Countryside could look for new economic opportunities in order to survive through tourism. But townscapes as tourist assets are viable if tourists can access them. There were previous cases which prompted rural population to see tourism as a viable option. In Ise, the opening of the Kintetsu railway in the 1960s attracted 13 million tourists in $1975,50 \%$ of them being from Kinki. Tourist townscapes could suffer the same pressures as urban ones, but some communities would see tourism not as a conflict but as an opportunity: examples like Tsumago ordinance (Fig. 4, number 9; Fig.5, number 2), based on the principle of 'do not sell, do not rent, do not scrap', tried to attract tourists without the original owners leaving the town. The ordinance was published after an old post in Tsumago, called Hayashi house, was put on sale. The local community opposed the sale and started a debate to take advantage of their townscape as 


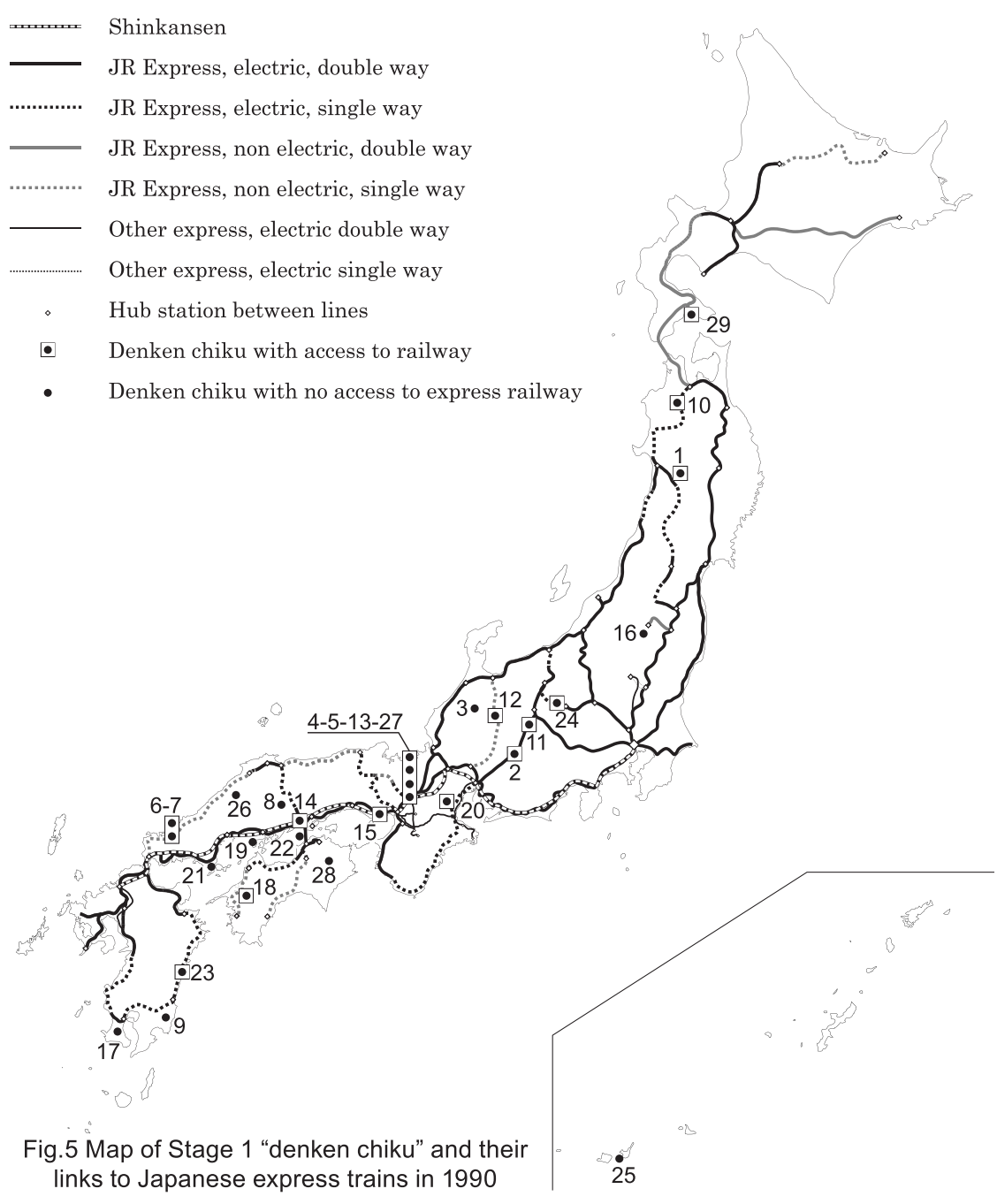

\begin{tabular}{|c|c|c|c|c|c|}
\hline District & A & B & $\mathrm{C}$ & $\mathrm{D}$ & $\mathrm{E}$ \\
\hline 1 Kakunodate & & - & & & \\
\hline 2 Tsumago juku & & - & & & \\
\hline 3 Shirakawa & & & & & $\bullet$ \\
\hline 4 Sanneizaka (Kyoto) & $\bullet$ & & & & \\
\hline 5 Gion Shinbashi (Kyoto) & $\bullet$ & & & & \\
\hline 6 Horiuchi chiku (Hagi) & & & $\bullet$ & & \\
\hline 7 Hiyako chiku (Hagi) & & & $\bullet$ & & \\
\hline 8 Fukiya & & & & & $\bullet$ \\
\hline 9 Obi & & & & $\bullet$ & \\
\hline 10 Naka chō (Hirosaki) & & & $\bullet$ & & \\
\hline 11 Narai & & $\bullet$ & & & \\
\hline 12 San machi (Takayama) & & & $\bullet$ & & \\
\hline 13 Saga Toriimoto (Kyoto) & - & & & & \\
\hline 14 Kurashiki & $\bullet$ & & & & \\
\hline 15 Kitano chō (Kōbe) & $\bullet$ & & & & \\
\hline 16 Ōuchi juku & & & & $\bullet$ & \\
\hline 17 Chiran & & & & & $\bullet$ \\
\hline 18 Yokaichi (Uchiko) & & & $\bullet$ & & \\
\hline 19 Takehara & & & & $\bullet$ & \\
\hline 20 Seki juku (Kameyama) & & & $\bullet$ & & \\
\hline 21 Furuichi Kanaya & & & & $\bullet$ & \\
\hline 22 Kasashima & & & & & $\bullet$ \\
\hline 23 Mimitsu & & & $\bullet$ & & \\
\hline 24 Unno juku & & $\bullet$ & & & \\
\hline 25 Taketomi jima & & & & & $\bullet$ \\
\hline 26 Ōmori Ginzan & & & & & $\bullet$ \\
\hline 27 Kamigamo (Kyoto) & $\bullet$ & & & & \\
\hline 28 Waki & & & & $\bullet$ & \\
\hline 29 Motomachi (Hakodate) & & & $\bullet$ & & \\
\hline Subtotal stage 1 & 6 & 4 & 8 & 5 & 6 \\
\hline Subtotal stage $1(\%)$ & 21 & 14 & 28 & 17 & 21 \\
\hline \multicolumn{6}{|c|}{$\begin{array}{l}\text { A- Shinkansen station at town; B- Electric, double } \\
\text { way limited express line; C- Limited express line; D- } \\
\text { Regular line; E- No railway access }\end{array}$} \\
\hline
\end{tabular}

a tourist asset. In fact, a little before, the electric train had arrived from Nagoya to Nakatsugawa. Magome district, another post town in Nakatsugawa and just few kilometres away from Tsumago, had received thousands of visitors. Tsumago community aspired to see some of those visitors arrived at Tsumago too (Ueno,2011).

In this context, the first towns with ordinances were located in : (a) urban locations with a high scrap-and-build pressure, especially along the Tokyo-Hakata axis (Kyoto, Kurashiki) or in secondary axes (Hagi, Matsue, Kanazawa, Morioka), and (b) rural or periurban locations that had taken advantage of the new infrastructures to attract tourism as a new economic activity (Yanagawa, Tsumago, Imajo). Fig. 4 shows how all these districts had access to the express railway network: all of them were in position to take advantage of the new trains.

\subsection{Stage 1: the rescue of urban areas and the new tourism}

When analysing the parallel evolution of infrastructure and the first 15 years of the denken chiku system, the pattern is remarkably similar to the previous stage. As seen in Fig. 5, 63\% of denken chiku in this stage had access to express trains. The first denken chiku were concentrated around well-developed railway infrastruc- ture areas, and the concentration was more intense in areas close to the shinkansen lines and in big urban areas.

Again, the scrap-and-build hazard in urban areas and the tourism opportunity in rural areas seem to be the main drivers of denken chiku nomination. Some communities followed the Tsumago model, aiming for kankō risson (lit. make a village a tourism destination). This also applied also to some of the denken chiku without railway access: Shirakawa (Fig.5, number 3) had a highly self-conscious community and has been the object of scholarly studies since the 19th century. Its community has built ties with Tsumago and aims to becoming a tourist asset. In the 1970s, they presented their village as a candidate for both denken chiku and UNESCO World Heritage Site declaration (Seizawa, 2006). They also entered the 'Discover Japan' campaign by Japan National Railways (Saitsu, 2006). Not having their expressway connection finished until 2008, Shirakawa would use Takayama station as the nearest access hub, by bus.

Very few rural townscapes avoided the tourist model: Yōkaichi (Fig. 5, number 18) was designated in 1982, but unlike previous examples, local authorities led the application process, despite significant opposition by the local community. Four years later, the new 


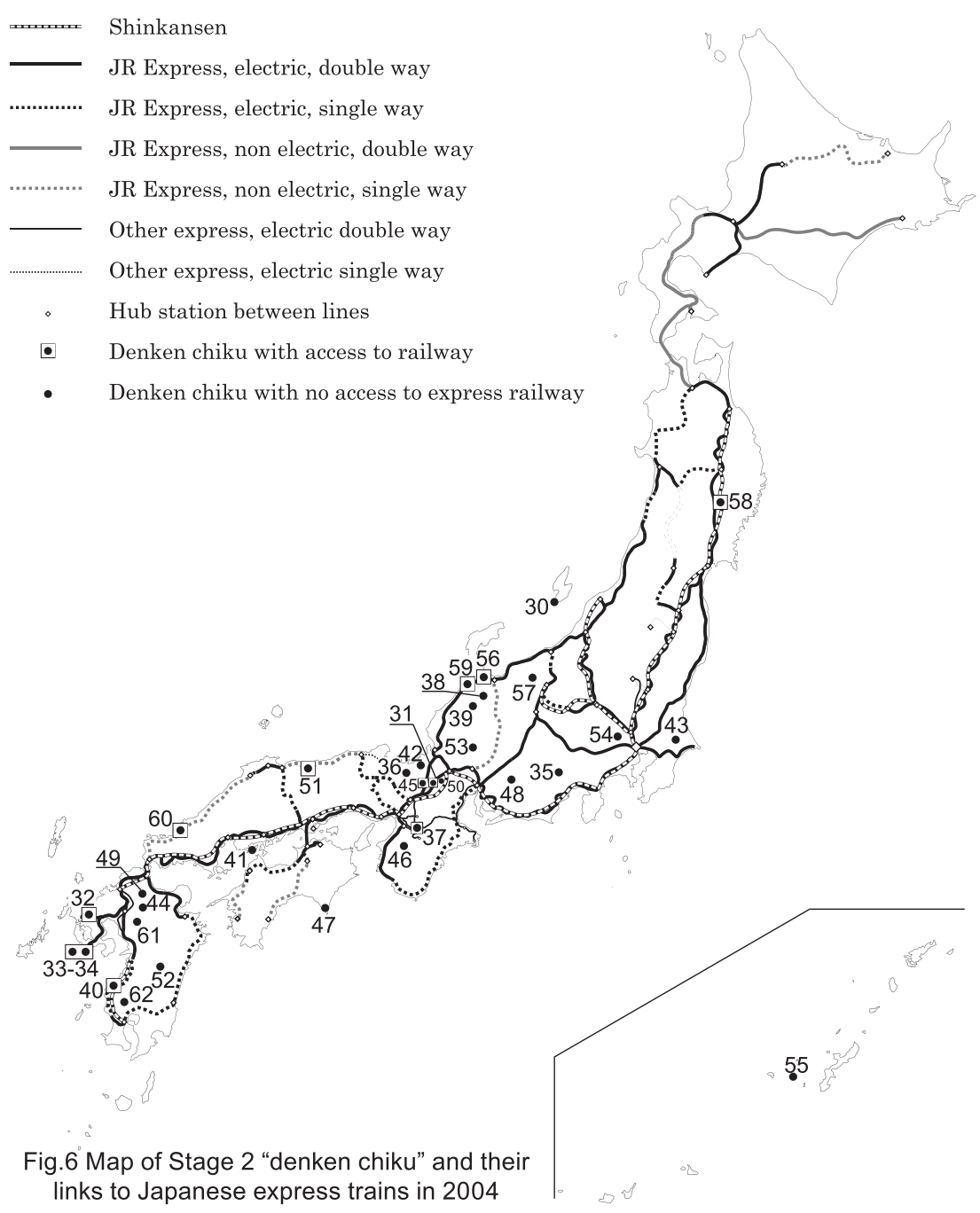

\begin{tabular}{|c|c|c|c|c|c|}
\hline District & $\mathrm{A}$ & $\mathrm{B}$ & $\mathrm{C}$ & $\mathrm{D}$ & $\mathrm{E}$ \\
\hline 30 Shukunegi (Sado) & & & & & - \\
\hline 31 Hachiman & & $\bullet$ & & & \\
\hline 32 Arita Uchiyama & & $\bullet$ & & & \\
\hline 33 Higashi Yamate & & $\bullet$ & & & \\
\hline 34 Minami Yamate & & $\bullet$ & & & \\
\hline 35 Akazawa & & & & & • \\
\hline 36 Miyama cho Kita & & & & & - \\
\hline 37 Imai chō & & $\bullet$ & & & \\
\hline 38 Ainokura & & & & & - \\
\hline 39 Suganuma & & & & & - \\
\hline 40 Izumi Fumoto & - & & & & \\
\hline 41 Yutaka machi Mitarai & & & & & - \\
\hline 42 Kumagawa juku & & & & & - \\
\hline 43 Sawara & & & & - & \\
\hline 44 Chikugo Yoshii & & & & - & \\
\hline 45 Sakamoto & & $\bullet$ & & & \\
\hline 46 Tondabayashi & & & & - & \\
\hline 47 Kiragawa & & & & & - \\
\hline 48 Iwamura & & & & & - \\
\hline 49 Akizuki & & & & & - \\
\hline 50 Gokashō Kondo & & & & - & \\
\hline 51 Kurayoshi & & & $\bullet$ & & \\
\hline 52 Tonegawa & & & & & - \\
\hline 53 Minō machi & & & & - & \\
\hline 54 Kawagoe & & & & - & \\
\hline 55 Tonaki jima & & & & & - \\
\hline 56 Yamachosuji & & $\bullet$ & & & \\
\hline 57 Hakuba mura Aoni & & & & & - \\
\hline 58 Jonai Suwakōji & $\bullet$ & & & & \\
\hline $\begin{array}{l}59 \text { Higashiyama } \\
\text { (Kanazawa) }\end{array}$ & & $\bullet$ & & & \\
\hline 60 Hamazaki (Hagi) & & & - & & \\
\hline 61 Yame Fukushima & & & & & • \\
\hline 62 Iriki Fumoto & $\bullet$ & & & & \\
\hline Subtotal stage 2 & 3 & 8 & 2 & 6 & 14 \\
\hline Subtotal stage $2(\%)$ & 9 & 24 & 6 & 18 & 42 \\
\hline \multicolumn{6}{|c|}{$\begin{array}{l}\text { A- Shinkansen station at town; B- Electric, double } \\
\text { way limited express line; C- Limited express line; D- } \\
\text { Regular line; E- No railway access }\end{array}$} \\
\hline
\end{tabular}

links to Japanese express trains in 2004

Yosan line allowed limited express trains stop in Uchiko (old Yosan line did not even pass through Uchiko). However, it still remained much like it did before the new railway, with commercial stores having remained as they were, and with a few tourism-oriented shops. Tourism was seen as a support for other existing economic activities, and unlike Tsumago or Shirakawa, they saw a conflict between the excessive growth of tourism and local lifestyle (Uchiko Town, 1983). Likewise, Fukiya (Fig.5, number 8) was proposed as a denken chiku candidate by external scholars, who surveyed the town and encouraged the community to preserve it, if purely for scholarly interest. Since tourism was not established as a goal, the difficult access to the village was not a problem. Currently, Fukiya is still difficult to reach by public transportation; yet only six of the first 29 denken chiku had no train access at all in 1990 (Fig. 5).

\subsection{Stage 2: the inclusion of slow-paced elements and places}

The Japanese model of tourism achieved poor results. According to Nishiyama (1990), the Japanese were not used to a slow-paced tourism due to their fast lifestyles. In addition, the new high-speed infrastructures allowed a single-day tourism model; however, the speed of tourists was not in accordance with the speed of the orig- inal townscapes. Rural areas would concentrate under $10 \%$ of the tourism even in the most rural prefectures. On the other hand, local reactions against kankō kōgai (lit. tourism pollution) had started during the previous decade. Thus, local movements started as a reaction to urban changes led by motorization and tourism pollution. In Waki (Fig. 5 number 28), local people opposed the local government due to the increase in tourism (Hohn, 1998). In Kyoto, locals rose against authorities when a project for a new pedestrian bridge between Gion and Pontochō was presented; the bridge was intended to be a sightseeing spot for tourists (Brumann, 2012). Massive tourism in Kyoto had already caused Sanneizaka district owners to transform their dwellings into shops (Nitschke, 1998).

Stage 2 denken chiku were not as concentrated around major infrastructures as before: $39 \%$ had access to express trains (Fig.6). The Japan government planned to have at least one denken chiku in every prefecture, included rural ones (Gutschow, 1998). When pressure on the major infrastructures stopped, the townscape protection system began to include older infrastructures such as ports, channels and the old Edo routes. Those old routes had a different speed vector than the new railways and were more consistent with the pace of denken chiku. Plus, networks could be made along those 


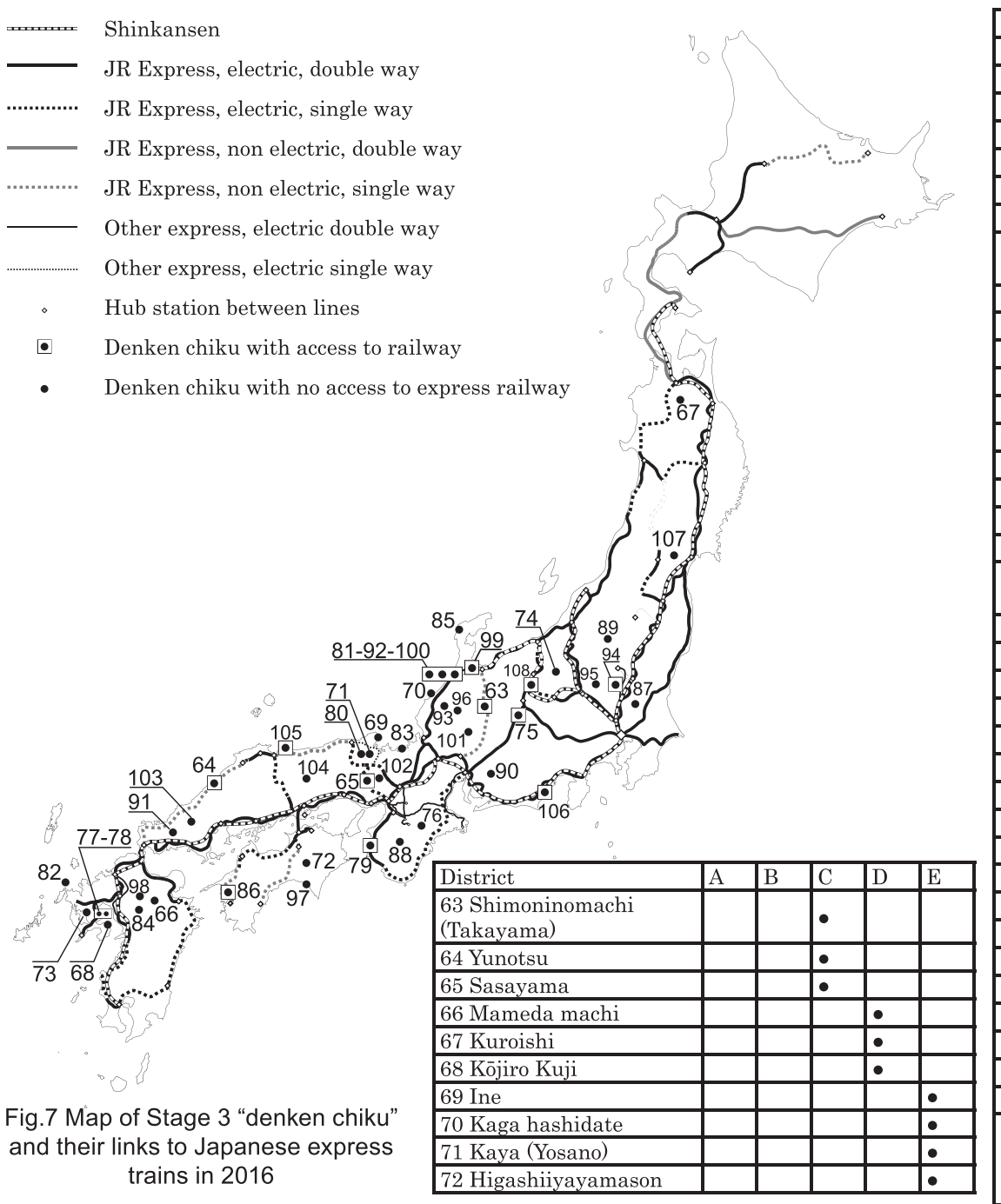

\begin{tabular}{|l|l|l|l|l|l|}
\hline 73 Shiotatsu & & & & & $\bullet$ \\
\hline 74 Akaiwa & & & & & $\bullet$ \\
\hline 75 Kiso Hirasawa & & $\bullet$ & & & \\
\hline 76 Matsuyama (Uda) & & & & & $\bullet$ \\
\hline 77 Hamakanayamachi & & $\bullet$ & & & \\
\hline 78 Hachiongishuku & & $\bullet$ & & & \\
\hline 79 Yuasa & & $\bullet$ & & & \\
\hline 80 Izushi & & & & & $\bullet$ \\
\hline $\begin{array}{l}\text { 81 Kazuemachi } \\
\text { (Kanazawa) }\end{array}$ & $\bullet$ & & & & \\
\hline 82 Ōshimamura & & & & & $\bullet$ \\
\hline 83 Obamanishigumi & & & & $\bullet$ & \\
\hline 84 Kurogi & & & & & $\bullet$ \\
\hline 85 Kuroshima chiku & & & & & $\bullet$ \\
\hline 86 Uno machi & & & $\bullet$ & & \\
\hline 87 Makabe & & & & & $\bullet$ \\
\hline 88 Gojo Shinmachi & & & & $\bullet$ & \\
\hline 89 Maezawa & & & & & $\bullet$ \\
\hline 90 Asuke & & & & & $\bullet$ \\
\hline 91 Sasanami & & & & & $\bullet$ \\
\hline $\begin{array}{l}\text { 92 Utatsu Sanroku } \\
\text { (Kanazawa) }\end{array}$ & $\bullet$ & & & & \\
\hline 93 Kaga higashitani & & & & & $\bullet$ \\
\hline 94 Kauemon cho & & $\bullet$ & & & \\
\hline 95 Kiryuu shinmachi & & & & $\bullet$ & \\
\hline 96 Shiramine & & & & & $\bullet$ \\
\hline 97 Doikachu & & & & & $\bullet$ \\
\hline 98 Tagomori & & & & & $\bullet$ \\
\hline 99 Kanayamachi & $\bullet$ & & & & \\
\hline 100 Teramachidai & $\bullet$ & & & & \\
\hline 101 Gujo Hachiman & & & & $\bullet$ & \\
\hline 102 Fukusumi & & & & & $\bullet$ \\
\hline 103 Tsuwano & & & & $\bullet$ & \\
\hline 104 Joutou & & & & $\bullet$ & \\
\hline 105 Tokorogo (Daisen) & & & $\bullet$ & & \\
\hline 106 Hanazawa & & $\bullet$ & & & \\
\hline 107 Murata & & & & & $\bullet$ \\
\hline 108 Inariyama & & $\bullet$ & & & \\
\hline Subtotal stage 3 & 4 & 7 & 5 & 9 & 21 \\
\hline Subtotal stage 3 (\%) & 9 & 15 & 11 & 20 & 46 \\
\hline $\begin{array}{l}\text { A- Shinkansen station at town; B- Electric, double } \\
\text { way limited express line; C- Limited express line; } \\
\text { Regular line; E- No railway access }\end{array}$ \\
\hline
\end{tabular}

routes: Kumagawa district, in Fukui (Fig.6 number 42), put effort into the valuation of the old route Saba kaidō, from Kyoto to Obama port. This would eventually lead Obamanishigumi (Fig.7, number 83) to become a denken chiku. Both districts would be more viable for tourism and local economic growth, in a model in which tourism would support other economic sectors instead of being the main activity.

Nonetheless, the intended economic and social regeneration of the rural zones was not achieved. The denken chiku system led to the preservation of townscapes when compared to those that did not enter the denken chiku category (Saio, Terao, 2014), but the tourism could not stop the population decline, as its economic impact was moderate.

\subsection{Stage 3: remote areas and local communities}

Even after 2004, the railway infrastructure continued to grow, especially the shinkansen network. By contrast, the old local lines, which ran parallel to the shinkansen network, were transferred to third party companies. These lines, found primarily in rural areas, tend to typically be on the verge of the bankruptcy (Shozawa, 2012, Kawashima, 1998), and the impact of tourism on these lines is small (Ackermann, 2016). Nonetheless, the new denken chiku are found mainly in rural areas, and they are often difficult to access, with only $25 \%$ of denken chiku having access to express trains (Fig.7)

The 2004 Landscape Law, the machizukuri in the 1990s, and the confirmation of the partial failure of the tourism-centred model provided an opportunity to change the approach: the protection of housings, landscapes and communities, while considering tourism as a small-scale activity. Landscapes, protected by the Landscape Law, were in remote areas, typically over $50 \mathrm{~km}$ from any shinkansen. Several remote areas grew in protection, like some natural spaces in San'In or Shikoku. The case of Yunotsu is significant (Fig.7, number 64): it is a part of the Iwami Ginzan UNESCO World Heritage Site since 2007. The site is composed of three towns, plus the traffic infrastructures that connected them and historic landmarks and landscape elements. Two of the towns in the site are denken chiku (Yunotsu and Ōmori Ginzan).

\section{Conclusion}

Tourism has been a factor serving to mobilize communities in favour of denken chiku designations. However, the approach towards 
tourism evolved once locals had reacted against tourism pollution. Before 1990, locals were generally encouraged by tourism-centred models. That is why the first denken chiku were typically in urban areas or areas easily accessible from urban areas, and they represented easy to understand machinami (lit. town rows), like post towns and samurai towns. At that time, the 'typical' house typology and street typology were in the centre of any survey and valuation. Only a few towns were protected for scholarly purposes, and their protection was encouraged by scholars or local authorities, rather than local people. And even so, the contents of surveys did not change much. By contrast, the latest denken chiku are typically in remote areas: instead of surveys based on 'typical', more values were added to surveys (landscape, composition of the community), resulting in a more complex analysis that went beyond easy to understand, street-like townscapes. Newly empowered communities rose throughout Japan, once the pressure of the bubble economy had ended. Tourism, as a trend, was seen as a support for community life and activity, thus community was positioned at the centre of townscape preservation as a major agent. That said, community changes have been more drastic in big towns and near major infrastructures (Jinnai, 1985) and were better preserved in remote areas. These remote areas could not possibly be protected in previous stages, but they represent a big portion of the latest townscapes valued as denken chiku.

\section{References}

1) ACA: 'Shūraku machinami gaido', Tokyo, 1989.

2) ACA: 'Nōrinsui sangyō ni kansuru bunkateki keikan no hogo ni kansuru chōsa kenkyū', Tokyo, 2003.

3) ACA: 'Rekishi wo ikashita machizukuri', Tokyo, 2015.

4) ACKERMANN, Peter: 'Tourism as a future for local rail services?', In ASSMANN, Stephanie (ed.) 'Sustainability in contemporary rural Japan. Challenges and opportunities', Routledge, London/New York, 2016.

5) BRUMANN, Christoph: 'Tradition, democracy and the townscape of Kyo' to', Routledge, London/New York, 2012.

6) CARBONARA Giovanni: 'Avvicinamento al restauro. Teoria, storia, monumenti', Liguori editore, Naples, 1997.

7) GEOSPATIAL INFORMATION AUTHORITY OF JAPAN. 'Chiriin Chizu', map database (https://maps.gsi.go.jp)(accessed 2016.1.15)

8) GIOVANNONI, Gustavo: 'L'urbanisme face aux villes anciennes', (Edited by CHOAY, Françoise), Editions du Seuil, Paris, 1998.

9) HENRICHSEN, Christoph: 'Historical outline of conservation legislation in Japan', in VV.AA. (Edited by ENDERS, Siegfried RCT, GUTSCHOW, Niels): 'Hozon: Architectural and urban conservation in Japan', Edition Axel Menges, Stuttgart/London 1998.

10) HAN, Ju Seong: 'Nihon ni okeru chōkyori kōsoku basu rosenmō no hattatsu', in 'Annals of The Tohoku Geographycal Asocciation', vol.47, 1995.

11) HOHN, Uta: 'Townscape Preservation in Japanese Urban Planning', in 'The Town Planning Review', 68, 2, 1997.4.

12) HOHN, Uta: 'Important preservation districts for groups of historic buildings', in VV.AA. (Edited by ENDERS, Siegfried RCT, GUTSCHOW, Niels): 'Hozon: Architectural and urban conservation in Japan', Edition Axel Menges, Stuttgart/London 1998.

13) ICOMOS: Venice Charter, 1964

14) ICOMOS: Nara Document, 1994.

15) INE TOWN, BOARD OF EDUCATION: 'Ine Ura dentōteki kenzōbutsu' gun hozon taisaku chōsa hōkokusho', Ine, 2005.

16) JAPAN GOVERNMENT: 'Bunkazai hogohō', 1950
17) JAPAN GOVERNMENT: 'Bunkazai hogohō kaisei', 1975

18) JAPAN GOVERNMENT: 'Keikanhō', 2004

19) JINNAI, Hidenobu: 'Tōkyō no kūkan jinruigaku', Chikumashobō, Tokyo, 1985

20) KAWASHIMA, Ryōzō: 'Tetsudō wa kuruma ni kateru ka', Chūō Shoin, Tokyo, 1998.

21) KOBAYASHI, Fumihiko; KAWAKAMI, Mitsuhiko: 'Policies implemented in the application process of preservation districts for groups of historic buildings', in 'Journal of Architecture and Planning (Transactions of AIJ)', n.567, pp. 87-94. 2003.5.

22) KŌJIRO, Junichirō; Meiji University Kōjiro Lab: 'Nihon no komyuniti', Kagoshima Shuppankai, Tokyo, 1975.

23) LARSEN, Knut Einar: 'Architectural preservation in Japan', ICOMOS International Wood Committee, Paris; Tapir, Trondheim, 1994

24) MLIT: 'Roads in Japan 2015', Ministry of Land, Infrastructure, Transport and Tourism, Tokyo, 2015.

25) NAKATANI, Norihito; MIFUNE, Tatsuo; FUKUSHIMA, Katsuya; SHIMIZU, Shigeatsu; ISHIKAWA, Hajime; OTAKA, Takashi; KIKUCHI, Akira: 'Kon Wajirō Nihon no minka saihō', Heibonsha, Tokyo, 2013.

26) NARIWA TOWN, BOARD OF EDUCATION: 'Bicchu Fukiya: machinami chōsa hōkokusho', Nariwa, 1977

27) NARIWA TOWN, BOARD OF EDUCATION: 'Dentōteki kenzōbutsugun hozon chiku minaoshi chōsa hōkokusho', Nariwa, 1991.

28) NITSCHKE, Gunter: 'Protection of urban place of Kyoto', in VV.AA. (Edited by ENDERS, Siegfried RCT, GUTSCHOW, Niels): 'Hozon: Architectural and urban conservation in Japan', Edition Axel Menges, Stuttgart/London 1998.

29) NISHIYAMA, Uzo: 'Rekishiteki keikan to machizukuri', Toshi Bunkasha, Tokyo, 1990.

30) SAIO, Naoko; TERAO, Yoshiaki: 'A study of sustainability of habitation in the historical preservation areas', in 'Journal of Architecture and Planning (Transactions of AIJ)', No.695, pp. 131-139, 2004.1.

31) SAITSU, Yumiko: 'Sekai isan no hozen to jūmin seikatsu. Shirakawa gō wo jirei ni shite', in 'Journal of Environmental Sociology', n.12, 2006.

32) SEIZAWA, Satohiro: 'Sekai isan no hozon to katsuyō wo sasaeru shakaiteki nettowāku. Gifu ken Shirakawa mura to Betonamu no jirei kara', in 'Bulletin of Research Institute', vol.14, Nara, 2006.

33) SHOZAWA, Hideki: 'Kokutetsu no kiso chishiki haisen kara kaitai made shōwa 20 nen - shōwa 62 nen', Sōgensha, Osaka, 2011.

34) SHOZAWA Hideki: 'Tetsudō chizu zannnen na rekishi', Chikuma shobō, Tokyo, 2012

35) SUZUKI, Mitsuru; SUGIMOTO, Toshimasa; MARUMO, Hiroyuki; SAKOGAICHI, Hiroshi: 'Uchiko chō no toshi kōzō keikan ni kansuru kenkyū I', in 'Nihon kenchiku gakkai Chūgoku shibu kenkyū hōkokushū', vol. 7 n.2, 1980 .

36) TAKAHASHI CITY: 'Takahashi shi Fukiya: dentōteki kenzōbutsugun hozon chiku minaoshi chōsa', Takahashi, 2013.

37) TAKEBE, Kenichi: 'Nihon kansen dōromō no shiteki hensen to tokushitsu', in 'Proceedings of the Japan Society of Civil Engineers', n.359, 1985.

38) UCHIKO TOWN, COMPREHENSIVE REGIONAL PLANNING OFFICE: 'Uchiko no 'hikari' wo 'mi' naosō. Uchiko chō kankō shinkō keikak' usho', Uchiko, 1983.

39) UCHIKO TOWN, CONFERENCE FOR HISTORICAL TOWN PRESERVATION: 'Kurashi ni ikizuku ikita machinami hozon wo mezashite. Dentōteki kenzōbutsugun hozon taisaku chōsa hōkokusho no aramashi', Uchiko town, 1987.

40) UENO, Kunikazu: 'Conservazione urbana a Tsumago', in GIANIGHIAN, G; DARIO PAOLUCCI, M: 'Il restauro in Giappone', Alinea Editrice, Firenze, 2011

41) UNESCO WORLD HERITAGE CENTRE (KAWAKAMI, Kaori, ed.): 'Understanding World Heritage in Asia and the Pacific. The Second Cycle of Periodic Reporting 2010-2012', UNESCO, Paris, 2012.

42) YAMASAKI, Masafumi: 'Control Tools for Conservation of Historic Townscape with Citizens' Strong Property Right: Experience of Kyoto', ICOMOS 15th General Assembly and Scientific Symposium, 2005. 


\section{和文要約}

本論文では二つの目標を設定している。一つは、重要伝統的建造 物群（以下、伝建地区）の決定方針変化を述べることである。その 変化は新しい理論的アプローチ、及び政策によってもたらされた。 もう一つは、上述の変化により、伝建地区に決定可能な地区タイプ の幅が広がったことを述べることである。本論文の主な仮説は伝建 地区決定が観光業を中心とした経済成長モデルからコミュニティを 中心とした経済成長モデルにシフトしたこととする。

そのために、総合的な参考文献を複数用いた基礎的調查を実施し た。その調査の内容は年々決定された伝建地区を位置、決定年、夕 イプ、都会又は地方への属性、経済成長を支えた交通機関との関係 による五つの観点からの分類である。更に文献調査を補うべく現場 調查を実施した。日本における町並み保存の行方に関する文献に基 づいて、1950年の「文化財保護法」から現在まで4つのステージに 分けて町並み保存の行方を述べた（図 2）。1950１975年のステー ジは伝建地区の以前なので、ステージ 0 とした。ステージ 1 は 1975 〜1990年の間で、バブル経済の成長期間とした。ステージ 2 は1990 〜2004年の間で、文化庁による伝建地区制度の予算の急増という特 徵が挙げられる。最後に、文化財保護法改正以降の 2004 年以来をス テージ 3 とした。以下にその推移を紹介する。

ステージ0には、文化財保護法のきっかけによる日本の文化財保 存の特殊なスタンスが形成した。そのスタンスにより保存される街 並みは「建造物群」である。そういった建造物群は文化財とされる 個別な建造物の有無に関わらず、集合として価值があるとされる。

日本におけるスタンスは二つの理論的アプローチに起因してい る。一つは景観保護のアプローチである。近現代の発達した交通機 関による景観悪化に反対の意見が挙げられたことで（西山、1990 ）1966年の古都保護法が策定された。もう一つは民家保護のアプロ 一チである。1950年における文化財保護法が民俗資料の文化財所産 として認められた結果、民家の学術的な興味が増加したのである。 その結果、倒壊の恐れがある民家が民家園等に移され、飛騨、明治 村、江戸村などが開始された。その後、地方におけるコミュニティ は古都のように自身の民家や景観を持続して観光活動を活かすこと を希望して、保存条例を決定した(図2)。その後、1975年文化財保護 法改正によって伝建地区という文化財のカテゴリーが認められた。

上記改正により、年々決定された伝建地区の分類上で、ステージ 1 は宿場・城下町、ステージ 2 は商家町・港町、ステージ 3 は集落 の分類が多いことが判明した (図 1)。しかも、年々の伝建地区の増 加速度から見ると、1990年以降は速度が急激に上がり、2004年以降 は更に上がったと分かる。位置から見ると、1990年以前は都会の伝 建地区が優先されたと言っても良い(小林、川上、2003)。交通機関 との関係から見ると、決定された伝建地区は徐々に高速鉄道路線（ 新幹線、特急電車のある路線）から遠ざかっていき、電車にアクセ スが全くない伝建地区が増加したと判明した(図5, 6, 7)。従って、伝 建地区の位置、決定年、タイプ、都会又は田地方への属性、経済成 長を支えた交通機関との関係による五つの観点から前述のステージ 分けを確認した。続いて、参考文献や現場調査のデータを用いてそ の変化の原因を調查し、分析結果を述べる。

ステージ1は都会や交通機関から近い町並みが優先されながら伝建 地区の決定が進んだ。それは、規制緩和によるバブル経済をハザー
ドとした場所が優先されたと考えられる。更に交通機関から近くに 位置する地方の町並を見ると、伝建地区決定によりその地域を観光 地化することが希望された。観光として相応しくするには、町並が 特に外観面で評価されていたと考えられる。その後、外観のみ保存 され、建造物の中が改築され、町並空間の用途も変化してきた。そ の事例には、南木曽町妻籠宿で宿場の用途の変化が挙げられる（上 野、2011）。建物全体が住宅・宿場の用途から、一階が商店・二階 が住宅に変化して、用途も雾囲気も変化した。

そこで、規制緩和及び観光公害により被害を被ったコミュニティ で町づくり活動が成長していった(西山、1990)。町づくりを通じて コミュニティが自分の住まいを守りながら、観光だけに頼らず経済 成長を狙った。そして、1990年にバブル経済が終わり、観光客数も 減ったが、バブル経済による改築の恐れも減った。それは、観光や 改築に集中せず、コミュニティに集中するモデルが発達する機会と なった。日本政府は伝建地区に使う予算も増幅させ、伝建地区にお ける研究も支援した。研究の成果物が日本にも海外にも出版され た。(図2)

ステージ2に決定された伝建地区を見ると、観光に重要な現代的交 通機関に近い場所が減少し、江戸時代以前の街路や水路に近い場所 が増加したと分かる。その古いインフラと共に、インフラに沿って いる町並みがシステム的に評価されるようになった。従って、イン フラに並ぶ商家町と港町の分類が最も多くなった。街道のシステム 的な評価の事例として、鯖街道には若狭町熊川宿と小浜市西組とい う二つの伝建地区がある。そこで「鯖街道ネットワーク」という共 同ネットワークが開始された。

次に2004年に景観法が決定された。コミュニティの生活に重要な 景観を保護するために、文化財保護法に文化的景観の種類が含ま れ、ステージ 3 が開始した。地方ではそのままのコミュニティ及び 景観が生き残っており、伝建地区の決定が地方に多かった。その結 果、最も増えた分類は地方にある集落となった。

以上のことから、現在において、決定されている伝建地区のモデ ルは変わって来たという結論に至る。現在は観光は主な活動ではな く、コミュニティの生活を支える活動とされており、コミュニティ が強い場所にシフトした。そのシフトの結果、分かりやすい町並に 限らず、景観やコミュニティなどの要素を配慮するモデルに移行し たと考えられる。1990年以前、優先された位置は都会及び交通機関 の近所だったが、現在は都会及び交通機関から離れている位置が増 えてきた。そのような地域は1976年に伝建地区に決定されることは 難しかったであろう。それは、コミュニティを配慮するシステムに なり、そのコミュニティが都会で最も激しく変わってきたのことか らだと考えられる。

(2016 年 8 月 10 日原稿受理, 2017 年 3 月 14 日採用決定) 